\title{
Áður dauðadómur - nú sjúkdómur
}

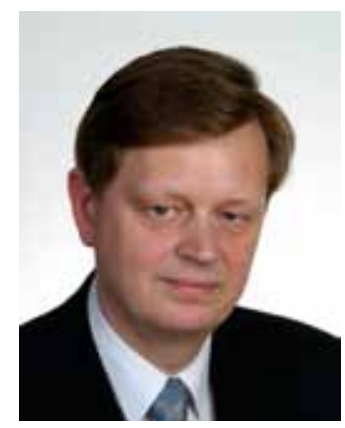

Jón Gunnlaugur Jónasson

jongj@krabb.is

Höfundur er yfirlæknir á Krabbameinsskrá Íslands, læknir á rannsóknarstofu í meinafræði, Landspítala og professor við læknadeild Háskóla Íslands.

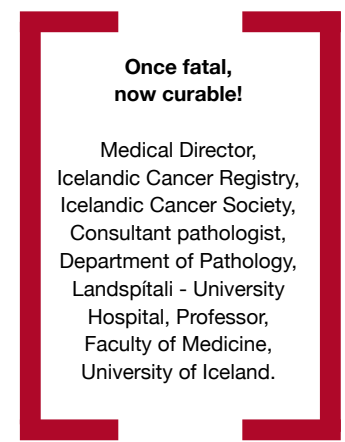

Einn af fyrrverandi forystumönnum Krabbameinsfélags Íslands sagði að pegar hann var að nema læknisfræði fyrir nokkrum áratugum hefði verið litið á krabbamein sem dauðadóm, en nú væri frekar litið á pað sem sjúkdóm. Pessi ágæti maður hafði mikið til síns máls. Möguleikar á greiningu og meðferð hafa gjörbreyst á undanförnum áratugum.

Við upphaf skráningar krabbameina á vegum Krabbameinsskrár Krabbameinsfélags Íslands, um miðjan sjötta áratuginn, greindust rúmlega 300 mein árlega en nú greinast tæplega 1400 ný tilfelli árlega. Petta er mikil aukning á tiltölulega skömmum tíma. Petta skýrist að miklu leyti af pví að hlutfall eldra fólks hefur aukist, en krabbamein er mun algengara í peim hópi. Krabbameinsskráin hefur möguleika á að leiðrétta fyrir fólksfjölgun og breyttri aldurssamsetningu pjóðarinnar. Pegar slíkt hefur verið gert sýnir sig að áhætta hvers einstaklings á pví að greinast með krabbamein nú er samt meiri en var fyrir tæplega hálfri öld og er raunveruleg áhættuaukning um 1-2\% á ári. Áður fyrr var oft vandkvæðum bundið að greina illkynja æxli, meðal annars vegna skorts á greiningaraðferðum. Á síðustu áratugum hefur bæði myndgreiningarrannsóknum og speglunarmöguleikum fleygt fram og ýmiss konar skurðtæknileg inngrip til pess að taka frumusýni og vefjasýni orðið möguleg. Petta allt hefur gert pað að verkum að mun auðveldara og áreiðanlegra er að greina illkynja sjúkdóma en á árum áður. Petta er að hluta til skýringin á fjölgun tilfella krabbameina.

Hlutfall sjúklinga sem lifir í fimm ár eða lengur eftir greiningu krabbameins hefur gjörbreyst á pessu tímabili og hækkað úr um 30\% í um $60 \%$, að teknu tilliti til aldurs og greiningarárs. Pessar bættu lífshorfur skýrast af ýmsu. Meinin greinast gjarnan á lægri stigum en áður og eru pví læknanlegri, aukin árvekni leiðir til pess að fleiri mein greinast snemma og sum peirra hefðu mögulega aldrei gert vart við sig og ekki haft áhrif á lífshorfur. Einnig kemur til bætt meðferð peirra sem greinast, bæði hvað varðar skurðlækningar, geislameðferð og lyfjameðferð. En pess ber að geta að krabbamein eru margir ólíkir sjúkdómar og horfur afar mismunandi eftir meinum.

Krabbameinsfélag Íslands minnist 60 ára afmælis síns á pessu ári. Í marsmánuði stendur félagið fyrir árvekniátakinu „Karlmenn og krabbamein", eins og síðastliðin ár. Árlega greinast yfir 700 karlar með krabbamein. Algengasta krabbamein peirra er blöðruhálskirtilskrabbamein. Í öðru sæti er krabbamein í lungum, pá krabbamein í ristli og endaparmi og pví næst er krabbamein í pvagvegum. Priðji hver karlmaður greinist með krabbamein einhvern tíma á lífsleiðinni og nú eru um 5000 karlmenn á lífi eftir krabbameinsgreiningu og margir peirra eru læknaðir.

Í pessu tölublaði Lxknablaðsins birtist grein um krabbamein í eistum, en pau eru algengustu æxli hjá karlmönnum milli 25 og 50 ára. Á undanförnum áratugum hefur orðið bylting í meðferð pessa sjúkdóms og fáheyrt er nú orðið að menn deyi af völdum hans.

Skimun fyrir krabbameinum hjá körlum á Íslandi hefur enn ekki hafist og eru ýmsar ástæður fyrir pví. Mæling á PSA-blóðgildi, sem mögulega væri unnt að nota við leit að krabbameini í blöðruhálskirtli, er ekki nægilega gott próf hvað varðar næmi og áreiðanleika og greinir ekki vel milli peirra sem purfa að fá krabbameinsmeðferð og hinna sem væru betur settir án meðferðar. Pví er ekki mælt með PSA-mælingu til skimunar. Hins vegar er til skimunarpróf við leit að ristilkrabbameini sem mælt er með að nota og byggist á pví að leita að blóði í hægðum. Mikilvægt er að skimun fyrir ristilkrabbameini hefjist sem fyrst.

Engu að síður skiptir miklu máli að karlar haldi árvekni sinni gagnvart einkennum og hugi að viðurkenndum forvörnum. Lungnakrabbameinsfaraldur síðustu aldar er í mikilli rénun vegna pess hve dregið hefur úr reykingum. Árið 1967 reyktu um 60\% íslenskra karla en nú er hlutfallið komið niður fyrir $20 \%$. Auk pess að forðast reykingar er líklegt að hægt sé að draga úr krabbameinsáhættu með pví að lifa heilbrigðu lífi almennt, gæta hófsemi og fjölbreytni í matarvenjum og hreyfa sig reglulega.

Fjölmargar vísindarannsóknir sem Ísland hefur tekið pátt í hafa sýnt fram á að lífshorfur krabbameinssjúklinga hér á landi eru með pví allra besta sem gerist í heiminum. Рað má meðal annars pakka góðu aðgengi almennings að hágæðaheilbrigðiskerfi par sem brugðist er við án tafa.

Við Íslendingar verðum að standa vörð um heilbrigðiskerfið sem skilað hefur pessum góða árangri. 